\title{
Higher Education, Infrastructure and Foreign Direct Investment in Pakistan
}

\author{
SaqibUsman \\ (M. Phil Scholar), Salman Masood (Ph. D Scholar), M Tahir Akbar, Superior University Lahore
}

\begin{abstract}
:
The main purpose of this paper is to check the correlation between higher education, infrastructure and foreign direct investment in randomly selected countries. Data on higher education and infrastructure have been taken from World Economic Forum's Global Competitiveness Indicators. Data on foreign direct investment have been taken from the World Bank. Correlation between the selected variables has been checked through SPSS v.16. Both higher education and infrastructure are significantly correlated with foreign direct investment inflows in selected countries. It is recommended that Government of Pakistan must pay high attention to higher education and infrastructure development if Pakistan wants to attract more foreign direct investment inflows for economic development. Data have been taken for a limited time period and for a limited number of countries. Better picture of the analysis can be reached if at least 20-25 years data of maximum countries are taken for analysis. Future research can include the role of government policy making in attracting the foreign direct investment inflows in host countries.
\end{abstract}

\section{Introduction}

This paper addresses the association between higher education, infrastructure and foreign direct investment in 22 selected countries. Countries have been selected from 6 continents and are divided into three categories i.e. factor driven economies, efficiency driven economies and innovation driven economies. According to State Bank of Pakistan, Pakistan is losing foreign direct investment for the last 8 to 9 years. Pakistan got US $\$ 2.7$ billion investment in the year 2009 and reducing to US $\$ 0.71$ billion in 2012 . Today Pakistan is facing severe energy crisis and there is a dire need to invest in the energy sector. But various factors are deterring local and foreign investors to invest in the energy sector at the time. Due to energy shortage, mills are shutting down and capital flight is occurring at a great speed, so it causes unemployment problems for the labor force of Pakistan. Government of Pakistan should pay utmost attention to energy problem and actually it is doing many things to solve this issue. But what factors are important that could attract foreign investors to invest in energy sector? This paper will attempt to answer this question.

There could be many factors that an investor would think of while deciding about investing in any particular country. These could be government policies about foreign direct investment, terrorism, education of the workforce, social and cultural environment, size of the market, security of property, infrastructure availability and quality and strategic location of the host country.

We have considered only two factors that an investor can think of from these factors. These are higher education and infrastructure. We will check whether these two variables are being considered by investors while contemplating to invest in the host economy.

We have used World Economic Forum's World Competitiveness data for higher education and infrastructure and World Bank's data for foreign direct investment. We used correlation to check the association between these variables.

\section{FDI and Economic Development}

\section{Literature Review}

Laura Alfaro (2006) compared the effects of FDI on both developed and under-developed economies and found that FDI or production of the foreign firms adds value to the economic development of the developed countries than under-developed countries. Laura Alfaro (2006) also found that quality of the workforce and structure of the market plays an important role in realizing the benefits of FDI on economic development of the countries observed.

Iftikhar (2012) empirically tested the relation between FDI and economic development of the countries including India, Pakistan and Bangladesh among others. Iftikhar (2012) observed that there is bi-directional causality between foreign direct investment and gross domestic growth of these countries. Berg (2006) concluded that FDI per year has positive effect on economic growth of the United States during 1970-2001. 
Ozturk (2007) wrote that researchers and policy makers agreed that FDI had significant effects on economic development of the host economies through capital accumulation, transfer of latest technology and enhancing the skills of the workforce.

Narula (2004) assumes that multinational enterprises and foreign direct investment can raise productivity and enhance exports but it is not necessary that these can increase capacity of the industry and competitiveness of the local firms which would actually tell about the long run sustainable growth of the economy. Narula (2004) further argues that a country can reap the full benefits of the FDI only when it has sound base of industrial sector.

Kjetil Bjorvatn (2002) concluded that it is not necessary for economic development to occur to have FDI but entry of the foreign companies in the host country may raise technological capacity and competition in the local economy. Kjetil Bjorvatn (2002) found that South Korea has not achieved economic development through FDI rather South Korea achieved economic development by different methods of attracting capital, acquiring latest technological machines from international vendors and hiring international experts to run these machines and to teach local workforce to run these machines.

Stanisic (2008) found that foreign direct investment can affect host country economy in two different ways. First effect of FDI is on economic growth and second effect of FDI is on exports of the host country. Stanisic (2008) found no positive significant relationship between foreign direct investment and economic growth. This was due to the fact that the observed countries were in transition phase and there was decreased production and unemployment in local firms. This could have significant negative effect on the positive effects of the FDI for economic development.

\section{Higher Education}

Kokko (2002) points to the importance of improving the education level and human capital to such an extent that labor force can quickly and easily adapt the foreign technology and both of the these variables can lead to sustained economic growth of the country in the long run. Multinational corporations (MNCs) can play an important role in improving the tertiary education in countries where these MNCs are contemplating to invest (Kokko, 2002).

Governments can also be encouraged to invest in higher education by MNCs as these MNCs demand highly skilled labor force from natural sciences, management and engineering (Kokko, 2002). Kokko (2002) argues that MNCs are actively playing an important role of improving the universities and institutions in the host countries alongside imparting scholarships for education.

Spillover benefits of these investments in higher education can only be realized when local firms have the capacity to absorb foreign technology, basic level of the workforce is there and competition barriers are not high (Kokko, 2002).

Varghese (2009) explored the link between globalization and higher education by explaining crossborder movement of the institutions, teachers and students. Varghese (2009) argues that proper regulations and framework is required to be there for multiple operators from private and cross-border institutions. If regulatory framework is absent from the equation it would not be possible to sustain the long term development of the country.

Barry (2005) focused on the connection between industry strategy of a country which is directed towards foreign direct investment and third level education system in Ireland. Barry (2005) concluded that MNCs are investing in R \& D in countries where local environment facilitates innovation.

Times Higher Education wrote that out of top 10, 6 universities are from United States. In 2006-07 over 580,000 foreign students were enrolled in the US universities. And there are 4,000 plus universities and colleges in the US. Additionally, 56 million of the US population has obtained a bachelor's degree or higher.The US companies and foreign affiliates take full advantage of this environment to succeed in globalized world. This environment also gives the US an attractive edge to attract foreign direct investment.

Sass (2003) states that macro-economic stability, infrastructure as well as education and training are very much important to attract capital in a country. Sass (2003) found that a key problem in attracting foreign direct investment is workforce not having medium level of education and also training methods of higher education are not up to the mark.

Firms cannot sustain growth in the absence of skilled labor force and also there is a strong link between higher education system of a country and its innovation ability. Don Almeida (2010) suggests that there is a need to focus on investment in the sector of education for at least one or two decades if a country wants to improve in industrial development and knowledge-based innovation.

Shatz (2001) recommends that in order to attract fresh investment in a country there is a need to develop markets, costs of trades should be lowered, improve export processing areas but among these better education (secondary and higher education) is highly important in the long run. Nunnenkamp (2002) suggests 
that if a country wants to reap maximum benefits from FDI, it should be able to absorb advanced technologies and also it should have higher levels of education.

Nowadays, education hubs are being created by the people for the purpose of training and education, knowledge and using all these activities for innovation purposes. For all these activities, cross-border interactions are being used by various stakeholders. Knight (2011) further studied these hubs by including students, skilled labor and knowledge and innovation hubs.

Khan (2007) argues that well-educated skilled workforce is helping countries to move from laborintensive to skill-based, advanced technological countries. Khan (2007) informs that South Asian countries focus on simple education level of the workforce, therefore knowledgeable and advanced skilled-based workforce is scarce in these countries. These conditions are highly detrimental in attracting foreign direct investment in these countries. Khan (2007) further argues that countries like Singapore, Malaysia, Korea and Ireland have successfully attracted and sustained foreign direct investment through human resource development.

The most important thing that (Khan, 2007) described is that Singapore without having sufficient natural resources had consistently attracted foreign direct investment through human resource development.

\section{Infrastructure}

Kwok-Chiu Fung (2011) states that US\$ 750 billion is required for infrastructure projects in East Asia and Pacific regions during 2010-2020. These projects include energy sector, telecom, transportation facility, supply of water and sanitation facilities. Kwok-Chiu Fung (2011) further informs that as production networks in Asian countries are expanding due to regional and global businesses, investment is highly needed in crossborder infrastructure projects having many complex issues with them. Financing of these projects is a big issue, so private sector investment should be encouraged in these projects.

Kwok-Chiu Fung(2011) recommends that cross-border infrastructure projects need huge investments because these projects would not only bring capital but technological knowledge and knowledge of managing these big projects.

Panitchpakdi (2009) wrote that physical infrastructure and technological infrastructure were among the key determinants of foreign direct investment. Panitchpakdi (2009) contends that regulations are necessary for mining in countries with vast natural resources and for countries with tourism attractions, tourism regulations are necessary for attracting foreign direct investment.

Kobayashi (2010) stated that in telecom sector, barriers were there for foreign ownership in landline telephone service, so this could be an area where foreign direct investment can be attracted if barriers to ownership were removed. Kobayashi (2010) further mentioned that FDI determinants such as size of the market, quality of the infrastructure, stable political system and potential for economic growth.

Countries in East Asia have attracted foreign direct investment by improving infrastructure facilities deliberately but in Indonesia, infrastructure facilities are not up to the mark to attract FDI (Sjöholm, 2010). Khan M. A. (2011) argues that Pakistan does not have proper infrastructure facilities to attract foreign direct investment and if there is FDI, it is concentrated in telecom, oil and gas and finance sector.

Shapiro (2002) argued that if a country had stable political infrastructure, it would be able to attract more multinational corporations. Ozturk (2007) recommends that for overall economic growth of the country, quality of the infrastructure, regional cooperation and sound banking system should be there to attract foreign direct investment.

There is association between foreign direct investment and economic growth of the country provided that the host country has achieved minimum educational level and infrastructure development (Ozturk, 2007). Steve Kapfer (2007) tested the theory that foreign aid for infrastructure (communication, transport and energy) would attract foreign direct investment. Steve Kapfer (2007) empirically proved that aid had no significant effect on foreign direct investment but aid for infrastructure had positive and significant effect on foreign direct investment.

Steve Kapfer (2007) suggested that countries receiving loans in the sectors of telecom and transport would be in a better position to attract foreign direct investment. Mwilima (2003) argues that networks of infrastructure including roads and electricity can encourage foreign investors to invest in the host countries.

In China variables attracting foreign direct investment include among others, low cost of labor, infrastructure quality, good policies for international trade, tax rates and exchange rates policies. M. Asim Faheem (2011) empirically proved if a country has good physical, technological and telecom infrastructure, it will be in a better position to attract foreign direct investment.

Behname (2012) concluded that urban infrastructure facilities had positive impact on foreign direct investment and he further recommended that governments in these countries should pay proper attention to these variables to attract foreign direct investment. Villanger (2004) found that poor macroeconomic policies, bad infrastructure and high regulatory environment deter foreign investors to invest in the host countries. 


\section{Theoretical Model}

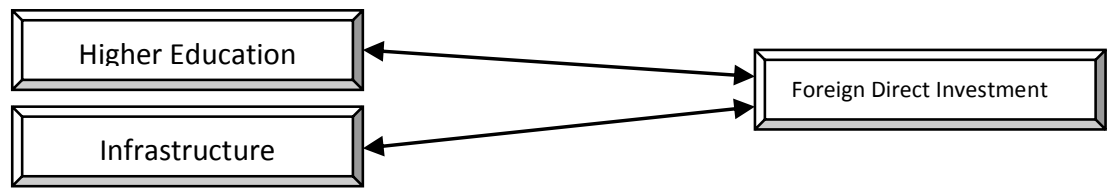

Correlation Model between Higher Education, Infrastructure and Foreign Direct Investment

\section{Research Hypotheses}

$\mathbf{H}_{\mathbf{0}}$ : There is no correlation between higher education, infrastructure and foreign direct investment.

$\mathbf{H}_{1}$ : There is correlation between higher education, infrastructure and foreign direct investment.

\section{Methodology}

The main purpose of this paper is to check whether there is any correlation between higher education, infrastructure and foreign direct investment in selected countries. Countries were selected from the 6 continents to give representation to the whole world. Also countries were divided among factor driven, efficiency driven and innovation driven economies. China and the USA were intentionally left out because they have huge FDI figures that could change the results extensively. Data on foreign direct investment have been taken from the World Bank for 2011 and data on higher education and infrastructure have been taken from the World Economic Forum for 2011. Data on FDI were awarded scales as (up to US\$ 1 billion = Poor, up to US\$ 3 billion = Satisfactory, up to US\$ 6 billion = Good, up to US\$11 billion = Very Good, US\$50 billion and above $=$ Excellent $)$. Data on higher education and infrastructure were assigned scales of $(2=$ Poor, $3=$ Satisfactory, $4=$ Good, $5=$ Very Good and $6=$ Excellent). World Economic Forum has scaled data from 1 to 7 scales but for our convenience we have assigned above mentioned scales to all the selected variables. Analysis was conducted with the help of correlation through SPSS v.16.

\section{Results}

Following table shows selected countries from factor driven, efficiency driven and innovation driven countries' point of view.

Table 1: Countries/economies at each stage of development.

\begin{tabular}{|l|l|l|l|l|}
\hline $\begin{array}{l}\text { Stage 1 Factor } \\
\text { Driven }\end{array}$ & Transition from 1 to 2 & $\begin{array}{l}\text { Stage 2 Efficiency } \\
\text { Driven }\end{array}$ & Transition from 2 to 3 & $\begin{array}{l}\text { Stage } \\
\text { Driven }\end{array}$ \\
\hline Bangladesh & Sri Lanka & Indonesia & Argentina & Australia \\
\hline India & & Morocco & Brazil & Austria \\
\hline Nigeria & & South Africa & Malaysia & Canada \\
\hline Pakistan & & & Mexico & Germany \\
\hline & & & Turkey & Norway \\
\hline & & & & Singapore \\
\hline & & & & Sweden \\
\hline & & & Switzerland \\
\hline
\end{tabular}

Source: The World Competitiveness Report 2012-2013 (World Economic Forum)

Following table shows the correlation between higher education, infrastructure and foreign direct investment. Data were not symmetrically distributed so non-parametric Kendall's tau b was applied to check the correlation between the variables.

\section{Correlations Coefficients}

\begin{tabular}{|c|c|c|c|c|c|}
\hline & & & $\begin{array}{ll}\begin{array}{l}\text { Foreign } \\
\text { Investment }\end{array} & \text { Direct } \\
\end{array}$ & Higher Education & Infrastructure \\
\hline \multirow[t]{3}{*}{$\begin{array}{l}\text { Kendall's tau } \\
\text { b }\end{array}$} & $\begin{array}{ll}\text { Foreign } & \text { Direct } \\
\text { Investment }\end{array}$ & $\begin{array}{l}\text { Correlation } \\
\text { Coefficient } \\
\text { Sig. (2-tailed) } \\
\text { N }\end{array}$ & $\begin{array}{l}1.000 \\
22 \\
\end{array}$ & $\begin{array}{l}.402 * \\
.018 \\
22\end{array}$ & $\begin{array}{l}.325^{*} \\
.039 \\
22\end{array}$ \\
\hline & Higher Education & $\begin{array}{l}\text { Correlation } \\
\text { Coefficient } \\
\text { Sig. (2-tailed) } \\
\mathrm{N} \\
\end{array}$ & $\begin{array}{l}.402 * \\
.018 \\
22 \\
\end{array}$ & $\begin{array}{l}1.000 \\
22 \\
\end{array}$ & $\begin{array}{l}.909 * * \\
.000 \\
22 \\
\end{array}$ \\
\hline & Infrastructure & $\begin{array}{l}\text { Correlation } \\
\text { Coefficient } \\
\text { Sig. (2-tailed) } \\
\text { N }\end{array}$ & $\begin{array}{l}.352^{*} \\
.039 \\
22\end{array}$ & $\begin{array}{l}.909 * * \\
.000 \\
22\end{array}$ & $\begin{array}{l}1.000 \\
22\end{array}$ \\
\hline
\end{tabular}


** Correlation is significant at 0.01 level. (2-tailed)

*Correlation is significant at 0.05 level. (2-tailed)

The correlation table shows that there is significant correlation between higher education and foreign direct investment and between infrastructure and foreign direct investment. Kendall's tau b correlation coefficient is 0.402 between higher education and foreign direct investment at $p=0.018<0.05$. This is moderate level significant correlation between the two variables. Correlation coefficient between infrastructure and foreign direct investment is 0.325 at $\mathrm{p}=0.039<0.05$. This is also significant but moderate level correlation between these two variables.

\section{Conclusion and Recommendations}

The results of our study are in conformity with the results of (Tien, 2010) who found that foreign higher education significantly determines the level of foreign direct investment inflows. Our study also confirms the results of (Vlad, 2011). Their results showed that higher education is more important variable than primary education in attracting foreign direct investment.

Our results are also in accordance with the results obtained by (Sjöholm, 2010) who observed that the determinants about locational decision of multinational corporations include higher education, better institutions and liberal trade policies. Salehizadeh (2005) found that highly educated employees and managers significantly attract the multinational firms' investments in the United States.

Khadaroo (2007) concluded that transportation as infrastructure plays an important role in attracting foreign direct investment in short and in the long run. OECD (2000) confirmed with the help of empirical analysis that the provinces that have world class infrastructure would attract more FDI inflows.

Todd J. Moss (2004) observed problems that hinder foreign direct investment in Sub-Saharan Africa. These include negative attitude of political parties, unfavorable infrastructure and business climate. Dlamini (2009) empirically tested the relationship between FDI and its determinants. He concluded that $76 \%$ change in FDI is due to the factors such as liberal trade policies, infrastructure, stable economic environment and market attraction.

Chauvin (2013) found bi-directional relation between infrastructure and foreign direct investment. Infrastructure strategically affects multinational's decisions to locate their investment places. Shamima Nasrin (2010) concluded that policy makers at home and international investors considered that infrastructure (uninterrupted power supply, transportation and gas) could be a great barrier in attraction of FDI.

It can be derived from the results of this study that higher education and infrastructure play an important role in attracting foreign direct investment to many countries of the globe. As we have taken 22 countries form 6 continents to check the association between higher education, infrastructure and foreign direct investment, the results have been significant for all the selected countries.

Possible limitations of the study could be that we have taken data only for one year i.e. 2011. Better results could have been obtained if more years have been included in analysis and for several more economies of the world.

So policy makers all over the world and especially in Pakistan can put maximum attention to these two variables so that international investors can be attracted to invest in Pakistan generally and especially in the power sector.

[1] http://www.sbp.org.pk.

\section{References}

[2] Barry, F. (2005). Third-Level Education, Foreign Direct Investment and Economic Boom in Ireland. Dublin: Centre for Economic Research .

[3] Behname, M. (2012). Foreign Direct Investment and Urban Infrastructure: An Evidence from Southern Asia. Advances in Management \& Applied Economics, 2(4), 253-259.

[4] Berg, A. G. (2006). Foreign Direct Investment and Economic Growth: A Time-Series Approach. Global Economy Journal, 6(1), 119.

[5] Chauvin, D. N. (2013). FDI Flows in the MENA Region: Features and Impacts. IEMS Emerging Market Brief, 13(1), 1-26.

[6] Dlamini, M. B. (2009). Determinants of foreign direct investment inflows in Swaziland. Journal of Development and Agricultural Economics , 1(5), 177-184.

[7] Don Almeida, R. C. (2010). Government's Many Roles in Fostering Innovation. PricewaterhouseCoopers LLP.

[8] Iftikhar, A. (2012). Foreign Direct Investment and Economic Growth in Selected SAARC Countries: A Causality Investigation Using Heterogeneous Panel Analysis. Interdisciplinary Journal of Contemporary Research in Business, 4(3), 121-144.

[9] Khadaroo, B. S. (2007). The Role of Transport Infrastructure in Attracting FDI in Africa. The African Economic Conference, (357370).

[10] Khan, D. M. (2007). Role of Human Capital in Attracting Foreign Direct Investment: A South Asian Perspective. SAARC Journal of Human Resource Development, 5-25.

[11] Khan, M. A. (2011). Foreign Direct Investment and Economic Growth in Pakistan: A Sectoral Analysis. Islamabad: Pakistan Institute of Development Economics.

[12] Kjetil Bjorvatn, H. J. (2002). The Role of FDI in Economic Development. Nordic Journal of Political Economy, 28, 109-126.

[13] Knight, J. (2011). Education Hubs: A Fad, a Brand, an Innovation? Journal of Studies in International Education, 15(3), 221-240.

[14] Kobayashi, J. D. (2010). Investing Across Borders. Washington, D.C.: The World Bank Group. 
[15] Kokko, M. B. (2002). FDI and Human Capital: A Research Agenda. OECD Development Centre.

[16] Kwok-Chiu Fung, A. G.-H. (2011). Foreign Direct Investment in Cross-Border Infrastructure Projects. Tokyo: Asian Development Bank Institute.

[17] Laura Alfaro, A. C.-O. (2006). How Does Foreign Direct Investment Promote Economic Growth? Exploring the Effects of Financial Markets on Linkages. University of Oregon.

[18] M. Asim Faheem, M. K. (2011). Factors Attracting FDI Inflow in China. Kuwait Chapter of Arabian Journal of Business and Management Review, 1(4), 128-137.

[19] Mwilima, N. (2003). Foreign Direct Investment in Africa. Labour Resource and Research Institute (LaRRI).

[20] Narula, S. L. (2004). Foreign Direct Investment and its Role in Economic Development: Do We Need a New Agenda? The European Journal of Development Research, 16(3), 447-464.

[21] Nunnenkamp, P. (2002). Foreign Direct Investment in Developing Countries: What Economists (Don't) Know and What Policymakers Should (Not) Do! Jaipur: CUTS Centre for International Trade, Economics \& Environment.

[22] OECD. (2000). Main Determinants and Impacts of Foreign Direct Investment on China's Economy. Directorate for Financial, Fiscal and Enterprise Affairs.

[23] Ozturk, I. (2007). Foreign Direct Investment - Growth Nexus: A Review of the Recent Literature. International Journal of Applied Econometrics and Quantitative Studies, 4(2), 79-98.

[24] Panitchpakdi, S. (2009). The Role of International Investment Agreements in Attracting Foreign Direct Investment to Developing Countries. United Nations Conference on Trade and Development (1-145). New York and Geneva: United Nations.

[25] Salehizadeh, M. (2005). Foreign Direct Investment Inflows and the US Economy: An Empirical Analysis. Economic Issues, 10(2), 29-50.

[26] Sass, M. (2003). Competitiveness and Economic Policies Related to Foreign Direct Investment . Ministry of Finance.

[27] Shamima Nasrin, A. B. (2010). A Study of Major Determinants and Hindrances of FDI inflow in Bangladesh. Aalborg East: DIR \& Department of Culture and Global Studies Aalborg University.

[28] Shapiro, S. G. (2002). National Political Infrastructure and Foreign Direct Investment. Ottawa: Industry Canada Research Publications Program.

[29] Shatz, H. J. (2001). Expanding Foreign Direct Investment in the Andean Countries. Center for International Development at Harvard University.

[30] Sjöholm, R. E. (2010). FDI and Growth in East Asia: Lessons for Indonesia. Stockholm: Research Institute of Industrial Economics.

[31] Stanisic, N. (2008). Do Foreign Direct Investments Increase the Economic Growth of Southeastern European Transition Economies? South-Eastern Europe Journal of Economics , 1, 29-38.

[32] Steve Kapfer, R. N. (2007). If You Build It, Will They Come? Foreign Aid's Effects on Foreign Direct Investment. 65th MPSA National Conference.

[33] Supplement, W. U. www.thes.co.uk.

[34] Tien, A. F. (2010). African Leaders: Their Education Abroad and FDI Flows. Institute for the Study of Labor IZA.

[35] Todd J. Moss, V. R. (2004). Is Africa's Skepticism of Foreign Capital Justified? Evidence from East African Firm Survey Data. Center for Global Development.

[36] Varghese, N. (2009). Globalization, economic crisis and national strategies for higher education development. Paris: International Institute for Educational Planning.

[37] Villanger, I. K. (2004). Promoting investment in small Caribbean states. Bergen: Chr. Michelsen Institute.

[38] Vlad, M. S. (2011). The Relationship between Education and Foreign Direct Investment: Testing the Inverse U Shape. European Journal of Economic and Political Studies, 4(1), 27-46. 